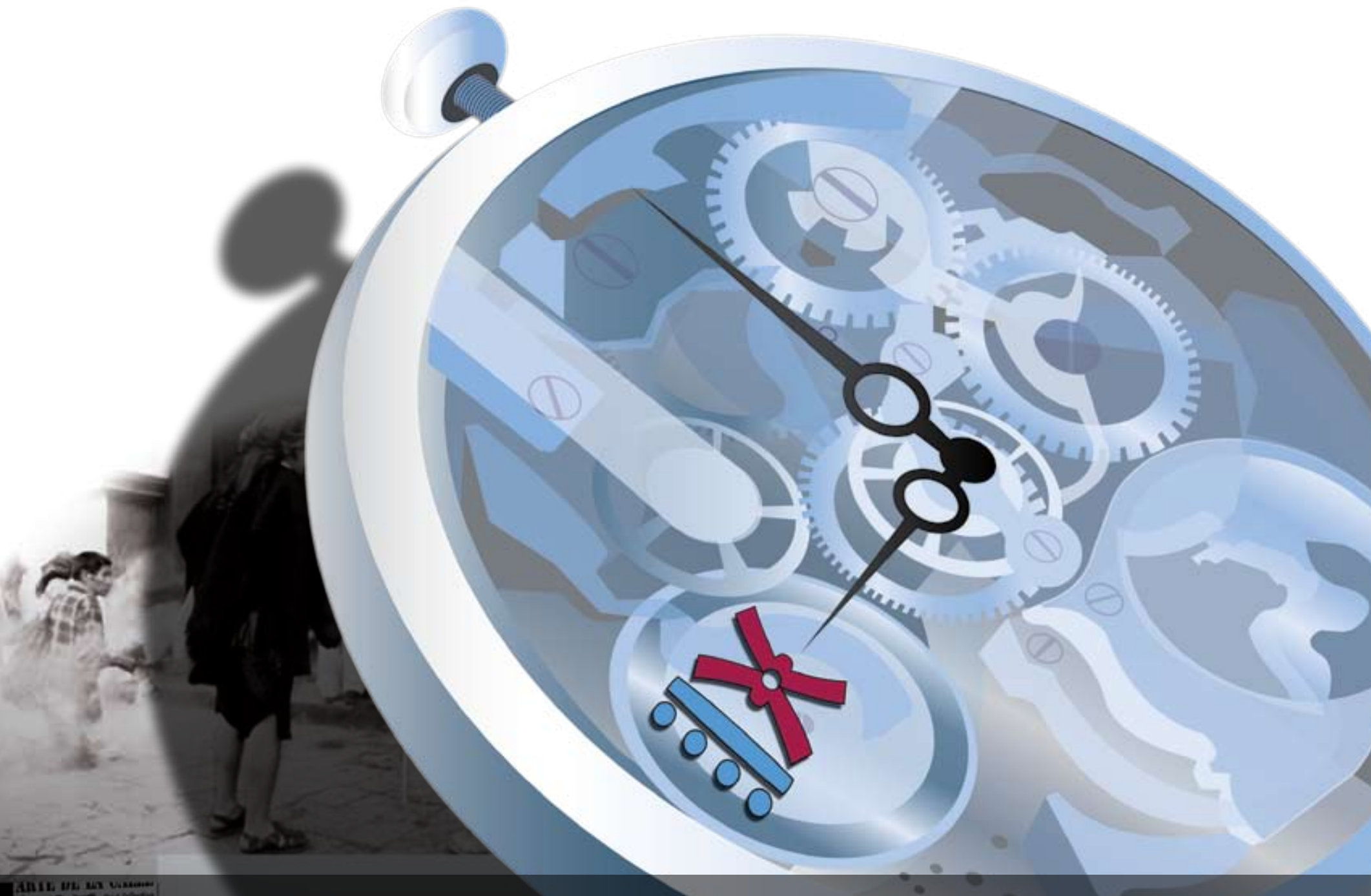

$\lambda 9^{\circ}$ CONGRESO Q 2 CENTROAMERICANO DE HISTOR I A

Universidad de Costa Rica ISSN 1409-469X

Fecha de recepción: 15 de mayo 2008 Fecha de aceptación: 30 de mayo 2008

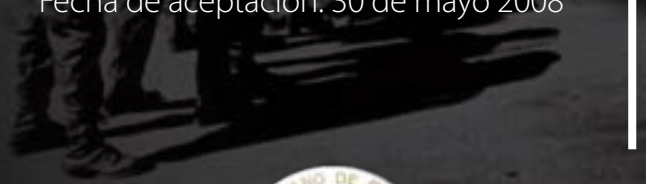

Las reformas liberales en El Salvador y sus implicaciones en el poder municipal, 1871-1890

Miembros del Consejo Editorial:

Dr. Ronny Viales, Dr. Juan José Marín

Editores Técnicos:

Allan Fonseca, Andrés Cruz, Gabriela Soto
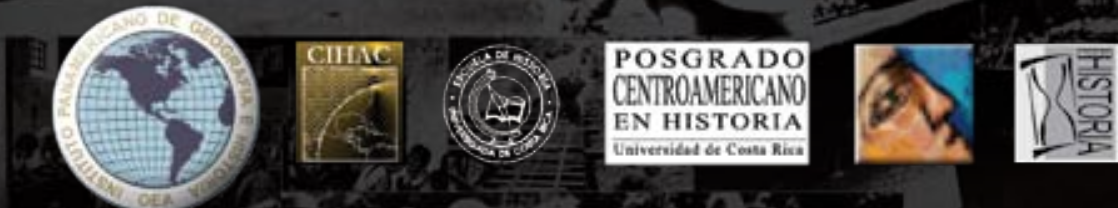


\section{Las reformas liberales en El Salvador y sus implicaciones en el poder municipal, 1871-1890}

\section{Carlos Gregorio Lopez Bernal}

Docente-investigador de la Licenciatura en historia

Universidad de El Salvador cglopezb@yahoo.com

Esta ponencia es resultado del proyecto de investigación 03.18 "Los municipios en el marco de la consolidación del liberalismo en El Salvador (1870-1900)"

desarrollado con el apoyo del Consejo de Investigaciones Científicas de la Universidad de El Salvador (CIC-UES).

El autor agradece al CIC-UES por el financiamiento del proyecto. Asimismo agradece a la Maestra María del Carmen Escobar, Directora de la Escuela de Ciencias Sociales, y a las autoridades de la Facultad de Ciencias y Humanidades por su apoyo. El bachiller Jorge Alberto

Martínez Rauda, estudiante de la Licenciatura en Historia, colaboró como asistente de investigación. 


\section{Resumen}

Este trabajo pretende entender el proceso de centralización del poder y construcción del Estado en El Salvador durante el último tercio del siglo XIX, a partir de las relaciones entre el poder central

— léase Ejecutivo - y el poder local representado por las municipalidades. En la primera parte se da un panorama general del contexto histórico del periodo y luego se estudian aspectos puntuales de las “reformas liberales” que muestran de qué manera estas afectaron a las municipalidades. Para ilustrar esos cambios se estudiarán las milicias locales, los mecanismos de control sobre el poder municipal, las implicaciones municipales de la privatización de ejidos, finalizando con los esfuerzos de las municipalidades por defender su autonomía y obtener mayores recursos.

\section{Las reformas y la consolidación del Estado (1871-1890)}

Este periodo es el más estudiado por la historiografía salvadoreña. Se le caracteriza por ser la época de las reformas liberales, las cuales se consideran como la culminación del proceso de centralización del poder y de consolidación del Estado. Generalmente este periodo se prolonga hasta finales del XIX e incluso hasta el levantamiento de 1932, al cual se ha visto como la manifestación de la crisis del estado liberal salvadoreño.

Si se acepta la tesis de que este periodo marca la consolidación del estado salvadoreño debe reconocerse que esta se dio en condiciones muy peculiares. En dicho periodo el país fue gobernado por los siguientes presidentes: Santiago González (abril de 1871 a enero de 1876); Andrés Valle (febrero-abril de 1876); Rafael Zaldívar (mayo de 1876 a mayo de 1885); Fernando Figueroa (mayo a junio de 1885); y Francisco Menéndez (junio de 1885 a junio de 1890). En realidad, los importantes fueron González, Zaldívar y Menéndez. Los tres lograron concluir su periodo constitucional sin mayores sobresaltos, pero no superaron la prueba del relevo presidencial.

De hecho, buena parte de la inestabilidad política del periodo se originó precisamente en la propensión de esos mandatarios a mantenerse en el poder, ya fuera reeligiéndose o arreglando la sucesión presidencial para conservar su influencia y dominio. El único que tuvo éxito con la primera modalidad fue Zaldívar, que se valió de amañadas reformas constitucionales y de elecciones convenientemente arregladas para gobernar por nueve años. González y Menéndez intentaron la segunda vía, pero fracasaron cuando los sucesores que intentaron imponer no fueron aceptados y terminaron derrocados. Es decir, la consolidación liberal en el poder no implicó 
necesariamente estabilidad política, ni respeto al orden constitucional.

El ascenso liberal finisecular se dio luego del derrocamiento de Francisco Dueñas. A partir de entonces dio inicio una serie de reformas que provocaron cambios importantes en lo político, lo económico y en las relaciones Estado-Iglesia y que complementaron transformaciones que se venían dando desde la década anterior. Los rasgos de las reformas liberales que más se ha destacado son: una marcada secularización de la sociedad, el irreversible desarrollo de la caficultura y significativos modificaciones en la tenencia y propiedad de la tierra. Pero también hubo importantes transformaciones culturales. Para entonces el país ya contaba con una importante comunidad intelectual que había abrazado los postulados del positivismo y la modernidad y que justificó y fortaleció desde las ideas los cambios en curso. La Iglesia y los indígenas fueron objeto de sus debates y ataques. La primera porque era vista como oscurantista y ligada a la tradición; los segundos porque eran percibidos como un obstáculo al progreso y la modernidad.

Los estudios históricos han hecho más énfasis en los aspectos políticos, económicos e ideológicos. En algunos casos se ha hecho referencia a los cambios culturales en el medio urbano, pero no se ha prestado suficiente atención a la cuestión cultural en sentido amplio; es decir, no se ha investigado hasta qué punto esas transformaciones alteraron el modo de vida de los indígenas y campesinos. ${ }^{1}$ Las reformas liberales supusieron el choque entre dos modelos de vida, que a pesar de sus evidentes diferencias, hasta entonces habían convivido en tensas pero relativamente equilibradas relaciones. Los indígenas, habían conservado cierta autonomía, al tiempo que participaban con relativo éxito en la economía y la política. ${ }^{2}$

Sin embargo, entre 1871 y 1890, los espacios de participación corporativa indígena se fueron reduciendo; la privatización de las tierras comunales tuvo nocivos efectos, no tanto en su situación económica, sino en su cohesión étnica, pero sobre todo debieron enfrentar una intransigente aunque quizá bien intencionada — ofensiva contra su forma de vida. ${ }^{3}$ Posiblemente esa presión haya sido una de las causas por las cuales los indígenas se involucraron tan decididamente en las movilizaciones políticas de 1885 y 1890, que quizá percibieron como las últimas oportunidades de revertir una evidente tendencia a la marginación y el sometimiento.

El rasgo más importante de las reformas liberales no fue su radicalidad, sino su continuidad. Aunque los sobresaltos políticos no desaparecieron, ninguna de las “revoluciones” del periodo consideró siquiera anular o cuestionar los cambios realizados anteriormente. Por el contrario, 
cada nuevo gobierno se comprometió en su profundización y consolidación. Es decir, dichas reformas no dependieron de la voluntad de una facción, sino de la claridad de una elite, que si bien no había encontrado la fórmula para hacer los relevos presidenciales tranquilamente, sí tenía claro el rumbo que quería darle al país.

Los cambios se centraron primeramente en el sistema político. Era lógico pues la mayoría de los conflictos internos que el país había vivido a lo largo del siglo habían estado determinados por disputas de poder. Sin embargo, la forma como se trató de resolver el problema fue muy poco original. Los "revolucionarios" siguieron la ya clásica receta: derrocar al "presidente usurpador", nombrar un presidente provisional, convocar a una asamblea constituyente que daría una nueva constitución - lo cual hace parecer que los problemas se originaban en ella, cuando en realidad tenían su origen en la incapacidad de los gobernantes para respetarla —, luego se convocaba a elecciones en las que indefectiblemente ganaba el individuo que había ejercido la presidencia provisoriamente. ${ }^{4}$ Esa fórmula no auguraba nada extraordinario, la prueba es que en 1876 el conflicto por la sucesión presidencial reapareció. Hubo que esperar varios años más y pasar por la dura experiencia de otras "revoluciones" para solucionar aceptablemente el problema del relevo presidencial.

Sin embargo, en los cinco años de relativa calma del gobierno de Santiago González la correlación de fuerzas se modificó significativamente. En septiembre de 1871 se presentó el primer proyecto de constitución que fue rechazado por el clero pues consideró que atentaba contra la religión. Pero el nuevo proyecto fue quizá más radical. El preámbulo de la constitución generó un absoluto rechazo del clero, ya que esta no se promulgaba en el nombre de Dios. Este simplemente aparecía como testigo de la soberanía popular que iba a expresarse en la nueva carta magna. ${ }^{5}$ Nuevos enfrentamientos se dieron cuando se discutió la libertad de culto. Al final se aceptó que la religión católica fuese la religión del Estado, pero tolerando el culto público de las sectas cristianas en lo que no ofendiera la moral y el orden público. El clero también rechazó tenazmente el artículo que inhabilitaba a los eclesiásticos para los puestos de elección popular, argumentando que mermaba sus derechos ciudadanos. ${ }^{6}$ Esas medidas, generaron descontentos que dieron lugar a dos importantes revueltas; una en Cojutepeque (1872) y otra en San Miguel (1874). En ambas hubo participación de del clero y fueron drásticamente reprimidas. Sin embargo, para entonces ya era evidente que cambiar el curso de las reformas sería muy difícil. 
A partir de 1871 el estado salvadoreño fue anulando o reduciendo los espacios de acción de la iglesia y de otras corporaciones como las municipalidades: registro civil, administración de cementerios, educación, cobro de impuestos, milicias locales, estadística, registro de la propiedad, etc. Poco a poco estos ámbitos de acción fueron subordinados al poder central, de tal manera que para finales de siglo el control del Estado se había fortalecido considerablemente.

Las reformas liberales fueron parte de una oleada revolucionaria que afectó casi simultáneamente a El Salvador, Honduras y Guatemala; de alguna manera eran un efecto retardado de la desaparición del caudillo conservador Rafael Carrera. Por unos pocos años se articuló un "triángulo liberal” que sintonizó la política regional, anulando la posibilidad de una “contrarrevolución” desde un país vecino, como había sucedido antes. Por otra parte, los cambios económicos que se habían venido dando desde la década anterior, abrían perspectivas inéditas y prometedoras. En esos años, la economía salvadoreña descansaba en dos pilares: el añil, que a pesar de sus altibajos todavía era una fuente de ingresos importante, y el café que cada vez tomaba más fuerza y se mostraba como el tan buscado "motor de la economía”. Para 1871, las exportaciones de añil alcanzaron 2, 308,317 de pesos y las de café 662,421. Pero en 1876, el añil reportó 1, 721,378 mientras que el café llegó a 1, 209,362. En 1884, el añil reportó 2, 073,752 pesos, y el café 2, 200,106. ${ }^{7}$ Sin embargo, ya para mediados de la década de 1880 el café había tomado ventaja sobre el añil que desde entonces marcó una tendencia a la baja no solo en la producción sino en los precios.

La configuración política regional y los cambios en la economía convencieron a los gobernantes de que había llegado la hora de profundizar los cambios. A su juicio, el crecimiento de la agricultura comercial requería cambiar la estructura agraria mediante la privatización de las tierras comunales y ejidales. Vale decir que hasta la década de 1870 el café se había expandido preferentemente en tierras privadas y en baldíos, aunque también se sembraba en ejidos y tierras comunales. Según Héctor Lindo, dos factores mantuvieron alejados a los terratenientes de las tierras ejidales y comunales: la existencia de tierras incultas, especialmente baldíos y el poder conservador guatemalteco. Sin embargo, los baldíos se estaban agotando y Carrera había desaparecido, más importante, "los conservadores salvadoreños no tenían interés en defender las instituciones tradicionales; se habían convertido en caficultores". ${ }^{8}$ Se llegó así a un nuevo escalón de cambios. Según la opinión liberal, al eliminar la propiedad corporativa se quitaban los obstáculos al desarrollo agrícola basado en la iniciativa particular y la seguridad jurídica. 
La mayoría de autores que han estudiado la privatización de las tierras ejidales y comunales concuerdan en que este proceso evidencia el fortalecimiento del estado salvadoreño y la elite que detentaba el poder, que obviamente se benefició de los cambios. No obstante, Aldo Lauria introduce matices interesantes. Según Lauria, los liberales veían a las tierras comunes, como "privilegios corporativos", propios del Antiguo Régimen colonial, por lo tanto no concordantes con el nuevo sistema político instaurado desde la independencia y que tenían entre sus principios y valores: soberanía, ciudadanía, propiedad e igualdad. ${ }^{9}$ Por lo tanto intentaron crear un sector social compuesto de labradores con visión empresarial y que tuviera garantizado el acceso a la tierra. Por otra parte, si bien acepta que para 1880 el estado estaba suficientemente consolidado para concebir, justificar y legislar una transformación tan importante, cuestiona la capacidad operativa estatal para realizar el proceso pues no se contaba con "agentes estatales" suficientes. Sin embargo, este problema se solucionó de una forma que puede ser vista como ejemplo de audacia, creatividad y pragmatismo, el gobierno logró que las reformas fueran ejecutadas por funcionarios locales, incluyendo líderes municipales y comunales. Esta decisión tuvo ventajas importantes. Por una parte le ahorró al estado recursos económicos y humanos; pero más importante, trasladó el potencial conflictivo de la privatización al plano local. Lauria señala las implicaciones a nivel local:

"La ejecución de la ley fue un asunto contencioso que provocó conflictos internos; las facciones comunales fueron colocadas unas contra otras, cada una tratando de asegurarse las mejores parcelas de tierras para sí misma. Pero las diferencias no se limitaron a luchas por el acceso a la tierra, conflictos políticos, a menudo relacionados con disputas más amplias ya fueran regionales o nacionales, afectaron la privatización y exacerbaron disputas internas y animosidades." 10

Para Lauria, el resultado inmediato de la privatización fue la división de la propiedad entre comuneros, ejidatarios y particulares que aprovecharon el momento para hacerse de tierras. Y si bien acepta que el proceso pudo prestarse para abusos por parte de terratenientes y funcionarios, considera que - en términos estrictamente individuales — ejidatarios y comuneros indígenas pudieron ver el proceso como positivo, ya que al menos inmediatamente, les garantizó el acceso a la tierra. Sin embargo, recalca que en el plano social las comunidades indígenas fueron las 
grandes perdedoras; no porque sus miembros hayan sido desposeídos de la tierra, sino porque se debilitó la cohesión comunal que se arraigaba en la tierra. A la larga, la propiedad individual actuó como fuerza centrífuga.

Paralelamente a los cambios políticos, a la secularización de la sociedad y la privatización de las tierras comunales y ejidales se continuó fortaleciendo al Estado y se destinaron cada vez más recursos a la construcción de infraestructura, especialmente carreteras, puertos, telecomunicaciones y ferrocarril. Asimismo se fortalecía al ejército y se trabajaba por mejorar los mecanismos de control social aplicando con más rigor las leyes contra los considerados vagos, los "quebradores de trabajo" y aquellos que insistían en "vivir en despoblado". ${ }^{11}$ La construcción de carreteras fue prioritaria pues garantizaba el flujo de los productos y un mejor control territorial. Una exposición del presidente González en 1874 da una idea del estado de la red carretera: "Las vías de comunicación terrestre con que hasta ahora contamos han recibido considerables reparaciones y mejoras, que si no pueden acelerar el movimiento del tráfico, contribuyen no poco á mantener su curso sin interrupción y á facilitar las transacciones indispensables al aumento progresivo de la riqueza pública." ${ }^{\text {212 }}$ Pero unas décadas después, los progresos eran notorios, al grado que el viajero francés Maurice de Perigni no dudó en afirmar: "Una característica de El Salvador es la excelencia de sus carreteras. Ellas son por demás esenciales para este pequeño país, rico, dotado de una población muy densa, gentes sobrias y laboriosas que no dejan improductiva la menor parcela de territorio." 13

Paralelamente a la construcción de carreteras se trabajó en la red ferroviaria y de telecomunicaciones. En 1882 se inauguró la vía férrea entre Acajutla y Sonsonate; en 1884 se completó el tramo entre Sonsonate y Armenia y en 1891 se extendió hasta La Ceiba. Para 1896 el ferrocarril había llegado hasta Santa Ana, principal centro productor de café. En el caso de las telecomunicaciones, los avances fueron también rápidos. La primera línea telegráfica fue inaugurada en 1870 entre el puerto de La Libertad y San Salvador. Cuatro años después se enlazó con Guatemala. La expansión del telégrafo comenzó en el occidente del país. Las municipalidades fueron obligadas a colaborar en el montaje y mantenimiento de la red telegráfica. En febrero de 1871 el gobernador de Sonsonate informaba al ministro de lo interior, que se había establecido el telégrafo a Izalco, por lo que encargó al juez de policía rural del distrito la inspección de las líneas. ${ }^{14}$ 
Un año después, el telégrafo se extendía en el departamento de San Vicente. El 24 de enero, la presidencia ordenó al gobernador que se diera a don Agustín Maury, contratista de la obra, "toda la gente que necesite para dicha empresa, siendo de cuenta del Sr. Maury la indemnización correspondiente”. El alcalde de Santo Domingo, recibió una nota el 16 de febrero, en la cual el gobernador le pedía personas "que se ocupen de extraer de los montes postes de madera de Madre de cacao, etc. desde la orilla del río Jiboa hasta el lindero con la jurisdicción... cuyos gastos pagará el empresario a su llegada á ese pueblo.”15 Para mediados de 1872, los indios de la región de Cojutepeque se levantaron contra el gobierno. El ministro de lo interior, Antonio Grimaldi pidió al gobernador que exigiera a las municipalidades "redoblar la vigilancia para la conservación de la línea telegráfica". ${ }^{16}$ Las telecomunicaciones y las carreteras aumentaron la capacidad de respuesta del ejército frente a las revueltas, pero también coadyuvaron a un mayor control de la administración pública en el interior. Para 1881, el gobernador de Cabañas decía que la correspondencia oficial y privada enviada por el telégrafo y correo se recibían con puntualidad. ${ }^{17}$

En 1882 se estableció el cable submarino que conectó al país con el resto del mundo. Hacia 1907 había 250 aparatos telegráficos en servicio y 600 empleados trabajaban en la red telegráfica. En 1888 se introdujo el teléfono. En 1914 el Directorio telefónico registró más de 1600 teléfonos distribuidos en todo el país, de los cuales 135 eran públicos. ${ }^{18}$ Ese desarrollo de la infraestructura garantizó el control territorial, obligando a que la población tomara conciencia del poder estatal que cada vez era más difícil de eludir.

Las reformas liberales señalan la culminación de un proceso de larga duración cuyo eje más evidente es el político, pero no pueden entenderse al margen de la economía y la configuración de una sociedad, cuyas raíces más vigorosas se nutrieron de la colonia. Se ha tendido a ver las reformas liberales como determinantes para la configuración del estado salvadoreño pues fueron las bases sobre las cuales el país se proyectó hacia el siglo XX. Eso es cierto, pero no debe olvidarse que también el pasado las condicionó. En cierto modo, estas fueron una versión postergada y actualizada de los audaces cambios que los primeros liberales intentaron hacer poco después de la independencia. La imposibilidad de realizar esas transformaciones evidencian no solo la debilidad y el apresuramiento de la elite que quiso impulsarlas, sino la fuerza de los factores en contra, y estos no provenían únicamente de los sectores sociales contrarios a los cambios. Cuando se revisan los recursos humanos y materiales disponibles, la intransigencia y 
prepotencia con que los ilustrados liberales quisieron imponer su agenda y la fuerza con que la Iglesia y las comunidades indígenas defendieron sus espacios, la tentación de afirmar que los “tiempos no estaban maduros" es grande.

Diferente era la situación hacia el último tercio del XIX. La elite se había fortalecido y estaba relativamente unificada. El poder central era suficiente como para imponerse a nivel local; como contraparte, la Iglesia y las comunidades indígenas se habían debilitado. Además, ya se contaba con una base económica que no solo generaba recursos fiscales para mantener un mínimo aparato burocrático, sino que obligaba a atemperar las pasiones políticas; de hecho, para finales de siglo, ya era muy común anteponer los intereses económicos a los impulsos políticoideológicos.

Esas transformaciones afectaron significativamente al poder local y provocaron una drástica redefinición de sus relaciones con el poder central. El denominador común del periodo fue la tendencia a subordinar lo local frente a los agentes del Ejecutivo, a la vez que se reducían los recursos y espacios de acción municipal, y se fortalecían y afinaban los mecanismos de control sobre las municipalidades. Al estudio de ese proceso de interacción entre poder central y poder local se dedicarán las siguientes páginas.

\section{Las milicias locales: del control municipal a las comandancias departamentales}

El 10 de diciembre de 1897, el gobernador de San Salvador transcribió al "Palacio del Ejecutivo" una nota del alcalde de Panchimalco, en la cual este denunciaba que el comandante del batallón de ese pueblo había mal informado a la municipalidad con el comandante mayor de plaza del departamento de San Salvador, producto de lo cual resultó que este los llamó ante el comandante de Panchimalco, al cual autorizó para que si los munícipes no le obedecían, procediera a encarcelarlos. El alcalde argumentaba que el problema se originó el día domingo 15 de noviembre cuando el comandante tenía formados a los milicianos en la plaza del pueblo y el regidor primero Magdaleno Jorge "entró en el círculo de la formación a hablarle al Comandante le diéramos milicianos para componer un barranco del camino que conduce a Olocuilta”. El comandante se enfureció “descargándole dos bofetadas y dos patadas, haciéndolo a presencia del Batallón”. El alcalde se quejaba de que el comandante maltrataba a la municipalidad, "nos trata con palabras ofensivas, nos ve con mucho desprecio, pues dice que solo él manda, menos el Alcalde”. ${ }^{19}$

Este incidente ejemplifica muy bien los cambios acaecidos en el manejo y control de las 
milicias locales, pero también muestra el nivel de subordinación a que había sido sometido el poder local. Los munícipes ya no mandaban las milicias, pero seguían obligados al mantenimiento de caminos; es por esa razón que el regidor pidió al comandante le proporcionara los milicianos para cumplir esa tarea. El Comandante no solo no le atendió, sino que lo agredió delante de los milicianos. Aún más, al tiempo que lo abofeteaba, expresó: "Usted no me manda, indio tonto tabanqueño", con lo cual dejaba en claro su poder sobre la municipalidad y sus prejuicios raciales. El comandante no desconocía a la municipalidad, pero dejaba en claro que su poder era superior al de aquella, y que los munícipes estaban a sus órdenes.

$\mathrm{Y}$ es que desde la primera mitad de la década de 1880 el gobierno central hizo esfuerzos sistemáticos y continuos por fortalecer el ejército y poner a las milicias locales bajo el control directo de oficiales militares. Asimismo se redujo paulatinamente el papel de las milicias indígenas. Patricia Alvarenga considera que estas medidas buscaban volver al Estado menos dependiente de instancias de poder local. Esa tendencia implicaba revertir las lógicas de poder hasta entonces vigentes; tanto las milicias locales comandadas por el alcalde municipal, como las milicias indígenas y ladinas — generalmente bajo las órdenes de jefes locales — habían sido aliadas importantes para las facciones políticas de la elite. Cualquier movilización en contra del gobierno precisaba del concurso de estas fuerzas. Igualmente, el gobierno amenazado por la oposición recurría a ellas en busca de apoyos extras a su causa. Obviamente, ese tipo de alianzas requería recompensas y prebendas. Ser parte de las milicias conllevaba un valor agregado importante para los poderes locales y les permitía no solo incidir en la política, sino tener una capacidad de veto sobre iniciativas que atentaban contra sus intereses. ${ }^{20}$

Durante los nueve años de gobierno de Rafael Zaldívar se realizaron importantes cambios en la organización del ejército y las milicias. Y es que las pretensiones del presidente de mantenerse en el poder lo obligaron a buscar mecanismos que le garantizaran mayor control sobre el ejército y menos dependencia de las tradicionales alianzas con otros sectores sociales. Se trató de quitar a los alcaldes y líderes indígenas el mando sobre las milicias locales; es decir se buscó dar al ejército permanencia y una estructura de mando vertical y efectiva, con lo cual se superaría el antiguo sistema de reclutamiento que dependía más de la negociación con los líderes indígenas y de la disposición de los alcaldes para la formación de las milicias locales. ${ }^{21}$ En síntesis, se buscó tener más fuerza permanente reclutada individualmente y al mando de oficiales de confianza, reducir las milicias locales y ponerlas bajo el mando de jefes militares del ejército. 
Para 1881 los resultados eran visibles. La memoria de marina y guerra afirmaba que la organización del ejército y las milicias había dado positivos resultados, sin que las actividades económicas hubieran sufrido menoscabo. Para entonces la fuerza militar ascendía a 18,500 hombres en toda la república, formando 17 batallones. El dictamen sobre la memoria dado por la Asamblea reafirmaba lo anterior: "La organización del ejército era una necesidad palmaria. Todos saben lo que costaba reunir una pequeña fuerza para cualquier asunto del servicio público y las malas consecuencias ocasionadas por el reclutamiento". Según el presidente de la Asamblea el decreto expedido para organizar las milicias remedió esos males. ${ }^{22}$

Hacia 1884 cada departamento contaba al menos con un cuartel. En 1891 la fuerza permanente era de 4,968 efectivos, pero a este núcleo básico se añadía el contingente aportado por las milicias que aumentaba considerablemente el total del ejército. Para 1892 estas contaban con 60,000 miembros. ${ }^{23}$ En la Memoria de Gobernación de 1893 se afirmaba que el total de la fuerza militar ascendía a 72,500 hombres..$^{24}$ Aunque estos datos deben tomarse con cautela, en conjunto reflejan una tendencia al fortalecimiento militar.

El grado de desarrollo de las milicias y la importancia que los gobernantes les daban puede apreciarse en el informe que en 1888 presentaba el gobernador político del oriental departamento de La Unión. Refiriéndose a su arribo al pueblo de Polorós, decía:

"Encontré reunidos á mi llegada como doscientos milicianos, los cuales se hallan bastante disciplinados, circunstancia que me hizo apreciar la actividad y celo del Comandante de estas fuerzas, que tienen una importancia relativa con motivo de ser también fronteriza esta población en la cual se hace necesario mantener fuerzas bien disciplinadas.” ${ }^{25}$

Resulta interesante constatar que esos “disciplinados” milicianos estaban bajo las órdenes de un comandante de milicias y no del alcalde del pueblo, como sucedía antes. Ese desplazamiento dio lugar a un mayor control sobre los milicianos, pues los comandantes tenían menos compromisos locales y además su fuero militar les daba mucho más poder sobre los a veces insumisos parroquianos. Esos cambios tuvieron consecuencias locales. Dejar de atender la instrucción de los milicianos y las "paradas dominicales” bien pudo ser un alivio para algunos alcaldes. Después de todo era una responsabilidad menos; además esos cargos a menudo generaban les traían conflictos con los vecinos o con las autoridades superiores. Sin embargo, el 
control de las milicias también reportaba ganancias políticas, pues daba a las municipalidades un argumento más en las pugnas de poder.

Por lo tanto, en el mediano plazo, perder el control de las milicias coadyuvó al debilitamiento del poder local. La presencia continua de militares en los pueblos dio a estos un poder que rápidamente se prestó a arbitrariedades como las denunciadas por el alcalde de Comasagua en febrero de 1887. Este refería que el capitán Carlos Escamilla, “valiéndose de sus armas y en estado de ebriedad", capturó al síndico municipal y lo puso en la cárcel. Con el apoyo del telegrafista y el secretario del juzgado de paz, Escamilla hizo que el detenido firmara una declaración; le recriminó que la municipalidad no obedecía las órdenes del gobernador y que por eso "el pueblo estaba hecho un revoltijo”. Además lo acusó de proteger al criminal Jesús Peinado. Al final el capitán le advirtió que "no era más que un síndico y que ya lo iba a hacer soldado para llevárselo a fuerza de chilillo”. El alcalde insistía en que las acciones de Escamilla contra la municipalidad eran recurrentes y que ya había encarcelado a varios munícipes. El desprecio del militar hacia la corporación municipal se manifestaba incluso en el uso de los utensilios; el alcalde resentía que Escamilla “utiliza el vaso que sirve para tomar agua para mandar a traer aguardiente”, convirtiendo la oficina "en una taberna, ayudado por sus soldados". ${ }^{26}$

\section{Fortalecimiento de los mecanismos de control sobre las municipalidades}

Paralelamente al fortalecimiento del ejército, el ejecutivo trabajaba en la búsqueda de mecanismos que le garantizaran un mayor control sobre las municipalidades. Esfuerzos de este tipo se venían haciendo desde la época de Gerardo Barrios y fueron continuados por Francisco Dueñas. La revolución liberal simplemente los profundizó. El 2 de octubre de 1872, el alcalde de San Esteban decía que “cumpliendo con la obligación de ley”, informaba sobre la administración local. Los rubros que tocaba eran los siguientes: Instrucción Pública, decía que la escuela era servida por un preceptor competente que no se limitaba a lo establecido en el reglamento, sino que impartía gramática castellana y aritmética (según las capacidades de los estudiantes) y que a la escuela concurría un número considerable de alumnos. Señalaba que la Justicia se administraba con puntualidad; la salubridad pública no había sido alterada; los caminos se encontraban en regular estado; en el caso de la agricultura se resentía no tener terrenos suficientes. En cuanto a las rentas municipales destacaba que se colectaban con la mayor energía posible. ${ }^{27}$ En el "Fondo de Gobernación” del AGN de las décadas de 1870 y 1880 aparecen numerosos informes como 
este; todos siguen el mismo formato, lo cual indica que el control sobre las municipalidades era mayor. Asimismo abundan los requerimientos y reparos a las cuentas de las administraciones municipales salientes.

Los informes de los gobernadores y las memorias de gobernación corroboran la capacidad de control del ejecutivo sobre las municipalidades. En 1881, Margarito González, gobernador de Cuscatlán, informaba que la mayor parte de las escuelas se encontraban en buen estado, "notándose el aumento de la concurrencia de niños". Agregaba que casi todas las poblaciones tenían edificios propios para las escuelas. Las carreteras estaban en buen estado de conservación; señalaba que había prevenido a las municipalidades "el exacto cumplimiento y apoyo decidido a las disposiciones emitidas con el laudable objeto de aumentar la producción cafetera" y finalizaba destacando el buen funcionamiento de la administración de rentas, correos y el servicio de telégrafo. ${ }^{28}$ Por su parte, el gobernador de San Vicente, decía que "Las municipalidades llenan su cometido observando estrictamente las prescripciones de la ley, protegen la persona y bienes de los asociados manteniéndolos en el goce de sus derechos, persiguen a los delincuentes y prestan con regularidad el servicio postal que por decreto de 3 de mayo se les ha encargado, administran sus rentas con integridad y en provecho común.” 29

En 1888 Doroteo Funes, gobernador de San Miguel, destacaba como uno de sus logros el envío puntual de las boletas de beneficencia por parte de los alcaldes. ${ }^{30}$ Resaltaba las obras de la municipalidad de San Miguel, contrastándola con los pueblos pequeños que no las realizaban por falta de fondos o por dedicar sus energías a otros menesteres; por ejemplo, la de Uluazapa que mantenía un litigio de tierras con un hacendado vecino. ${ }^{31}$ Para 1891, la memoria de gobernación, marina y guerra, daba cuenta de los “productos, gastos y existencias" de los fondos municipales de once departamentos. Aunque la mayoría de municipalidades presentaban saldos positivos, estos se reducían a unos pocos cientos de pesos. Solo unos pocos pueblos, entre ellos las ciudades más importantes, tenían existencias de más de mil pesos. Un caso excepcional fue Chalchuapa, en Santa Ana, que registró 4,596 pesos a favor. Para los intereses de este trabajo es importante destacar que solo cuatro pueblos no presentaron sus cuentas, lo cual sugiere que no las manejaban de acuerdo a los requerimientos establecidos. ${ }^{32}$

En todo caso, es evidente que para finales del XIX los gobernadores tenían mucho más control sobre las municipalidades. La energía con que la gobernación de San Miguel procedía se evidencia en la variedad de notas enviadas a los alcaldes. El uno de febrero de 1900 los 
previno para que a más tardar el día ocho presentaran a la gobernación las muestras de productos minerales, industriales y agrícolas que se mandarían a la exposición de París, de lo contrario les impondría una multa de 10 pesos. En agosto del mismo año, ordenó a la alcaldía de San Miguel anular las licencias para portación de armas que había extendido, por no hacer seguido el debido proceso; asimismo ordenó recoger a todas las mujeres prostitutas a fin de que fueran examinadas por el médico de venéreas e inscritas en el libro respectivo; también ordenó controlar la asistencia de los alumnos a las escuelas nacionales, multando como corresponde a los padres o encargados morosos y dando cuenta con esas multas a donde indica la nueva ley de arbitrios de Instrucción Pública. El nueve de octubre ordenó a los alcaldes del departamento presentar la nómina de ciudadanos respectiva para proceder a la calificación de jurados para el año de 1901, advirtiéndoles que de no cumplir pagarían 50 pesos de multa. El gobernador fiscalizaba hasta los juicios contra “quebradores de trabajo", e incluso ordenó destituir a Anacleto Rivera, encargado del alumbrado público de San Miguel, por mal desempeño de su cargo. Rivera fue enviado a la guarnición de la plaza de esa ciudad, "para imponerle un castigo severo, que sirviera de ejemplo a los demás." Seguramente que cuando el gobernador pensaba en "los demás” tenía en mente a otros funcionarios públicos. ${ }^{33}$

El afán de centralización también se nota en las rentas estatales. En la década de 1870 se puso especial atención a la renta de aguardiente. En 1873 se dio un reglamento para su administración, el cual se justificó en el artículo 43 de la constitución, que establecía que el gobierno debía administrar el ramo, sin descuidar la moral pública. El decreto en cuestión establecía: "se administrarán los aguardientes por cuenta de la Nación, con los empleados necesarios, la policía correspondiente y con la colaboración de empresarios que suministren el licor”. Las proveedurías serían licitadas y garantizadas con hipotecas. El artículo 16 establecía que en todo pueblo que tuviera municipalidad se mantendrían los puestos de ventas existentes a la fecha, pero el gobierno podía aumentarlos o disminuirlos "según las conveniencias de la renta i las necesidades de la moral pública”. Los asentistas se quedarían con un $12 \%$ de lo vendido en ciudades y villas y un $15 \%$ en pueblos pequeños. Los remates se harían por un año. Se establecía además que las tabernas solo tendrían una puerta para el despacho, al lado de la calle, cualquier otra existente en el local deberá ser “condenada”. Las tabernas abrirían en los días de trabajo de 6 a m a 6 p m, "i en los días festivos i en el inmediato siguiente, no más que desde las diez de la mañana hasta las dos de la tarde. Fuera de las horas determinadas no se venderá licor si no es con 
permiso escrito de alguna autoridad i con objetos medicinales, ó por pedido escrito de médico á cirujano". ${ }^{34}$

Todo el reglamento denota una clara intencionalidad de centralizar y controlar más efectivamente la producción y venta de licores, así como combatir el contrabando, sin dejar de lado la moral pública. Pero a diferencia de décadas anteriores tuvo más efectividad en su aplicación. El tomo XX de Impresos del AGN contiene abundante información y acuerdos en torno al aguardiente. En la memoria de Hacienda de 1874 se destacaba que la renta de aguardiente había pasado de 947,738.29 pesos, en 1872 a 1,222.015.50, en 1874, aumento que el ministro atribuía a la nueva legislación. ${ }^{35}$

En la búsqueda de un control más efectivo de los recursos, el ejecutivo se fue apropiando de espacios que antes fueron atribución municipal. El llamado fondo de beneficencia, que desde su creación había sido recolectado - y a veces administrado — por las municipalidades fue reformado en 1889. A partir de ese año la contribución de caminos se pagaría en efectivo, un peso por individuo de entre 16 y 60 años de edad, excepto los jornaleros que pagarían cuatro reales en moneda o trabajo personal. Dado que la categoría de jornalero seguía siendo vaga, se estableció que se consideraría como tal al "individuo que no teniendo trabajo propio, ó teniéndolo muy pequeño se dedica o puede dedicarse a los ajenos”. ${ }^{36} \mathrm{El}$ cambio más significativo era que el dinero recolectado pasaría directamente al fondo de caminos; los alcaldes podrían aprovechar la mano de obra en los caminos de su comprensión, debiendo llevar un libro especial para registrar los ingresos y las multas percibidas. Se establecía claramente que cualquier falta u omisión de los alcaldes sería sancionada con multas de uno a veinticinco pesos; las de los gobernadores se penaban de 25 a 100 pesos. Todas ingresarían al fondo de caminos. ${ }^{37}$

Medidas como la anterior solo serían efectivas si se garantizaba un mejor manejo de las cuentas municipales. En 1888 se dio un decreto que obligaba a todas las municipalidades de las cabeceras de departamento y de distrito a llevar su contabilidad por el sistema de partida doble. Las demás municipalidades podían registrar sus cuentas indistintamente, ya sea por cargo y data, o por partida doble. ${ }^{38}$ En concordancia con tal disposición, Hilario Alvarado, "contador municipal”, elaboró un manual sobre el modo de llevar las cuentas municipales. Guillermo Dawson y José María Cáceres dieron un dictamen favorable sobre la obra. Esta se dividía en dos partes: la primera explicaba como funcionan las cuentas bajo el sistema de cargo y data, y la segunda tomaba ejemplos de la primera pero aplicando el sistema de partida doble. En el prólogo 
señalaba que el sistema de cargo y data fue implantado en 1867 por Dionisio González, pero que a la fecha resultaba obsoleto. Para 1888 ya existía un Tribunal y contaduría municipal, que Alvarado consideraba muy importante para la mejora de la administración municipal. ${ }^{39}$

Seguramente que Alvarado era competente en contaduría, al grado que para 1889 fungía como contador de propios y arbitrios. En julio de ese año informaba al Ministro de gobernación sobre los trabajos del primer semestre. Había revisado las cuentas del año de 1887 de 73 municipalidades de los departamentos de San Miguel, Morazán, Usulután y La Unión. De estas aprobó 19, puso reparos a 52 y devolvió 2 por “inglosables”. También revisó las cuentas de cementerios; aprobó 127 y “reparó” 59. Señalaba que el total de las cuentas no aprobadas ascendía a 21,187.07 pesos; de los cuales 11,908.99 correspondía a las municipalidades (1887); 3,776.41 a cementerios; más 5,501.67 de las municipalidades de los departamentos de San Salvador y La Libertad, correspondientes a los primeros meses del año 88. ${ }^{40}$ Los resultados no eran muy halagadores. Un 78\% de las municipalidades no cumplieron con los requerimientos del nuevo sistema contable; el total de las cuentas “reparadas” ascendía a 17,410.63 pesos, cuyo manejo debió ser aclarado por los munícipes.

Posiblemente buena parte de los “reparos" hechos por Alvarado tenían que ver con la forma en que se llevaban las cuentas. En 1882, el ministro de gobernación decía al respecto: “Generalmente los secretarios llevan la cuenta municipal. En la mayor parte de las poblaciones los claveros no saben leer. Las partidas de cargo son firmadas a ruego de éstos, por el secretario... he aquí un vasto campo para que cometan estafas los secretarios de mala fe.”41 No es de extrañar entonces que en 1894 se diera un decreto que regulaba el nombramiento de los secretarios. Uno de los considerandos señalaba tajantemente que "la mala conducta de la mayor parte de los Secretarios Municipales es la causa principal del malestar de muchas poblaciones”, por lo que se establecía:

“Art. 1 Los nombramientos de Secretarios Municipales que hagan los Municipios deberán ser sometidos a la aprobación de los Alcaldes Jefes de Distrito, quienes lo aprobarán o no...

Art. 2 Los Alcaldes Jefes de Distrito, podrán destituir de su empleo a los Secretarios Municipales de su jurisdicción por conducta notoriamente viciada y abusos en el ejercicio de sus funciones. 
Art. 3. Todos los que quieran dedicarse al oficio de Secretario Municipal, ocurrirán a la Gobernación Departamental respectiva a inscribirse en un libro que se denominará 'Libro de patentes de Secretario Municipal'... Las municipalidades harán siempre el nombramiento de sus respectivos secretarios en personas patentadas". ${ }^{42}$

El decreto establecía un doble mecanismo de control. Por una parte los nombramientos debían ser aprobados por los Jefes de distrito, que además podían destituir a los secretarios; pero además, los aspirantes a secretarios debían estar registrados en el libro de patentes que era autorizado por el gobernador. A los secretarios en ejercicio se les daba sesenta días para registrarse.

En noviembre de 1881 se creó la Oficina Central de Estadística, el decreto que le dio vida afirmaba que era "de urgente necesidad el establecimiento de una oficina central en que se coleccione y se arreglen todos los datos estadísticos que puedan dar á conocer el desarrollo de nuestra industria, población y riqueza pública.”33 Para la segunda mitad de la década de 1880 esta dependencia publicaba en el Diario Oficial variados cuadros estadísticos. La lectura del Diario Oficial de la década de 1880 muestra un sostenido esfuerzo por afianzar el control estatal en todo el territorio. La publicación periódica de informes de los gobernadores políticos, inspectores de educación, las estadísticas de reos y los cuadros de las rentas cobradas en las aduanas se volvió muy frecuente, dejando entrever que el Estado se sentía poseedor de un control como nunca antes lo había tenido. ${ }^{44}$

\section{La privatización de los ejidos: implicaciones municipales}

Es bien conocido que en la década de 1880 se privatizaron los ejidos y las tierras comunales. Se ha estudiado con bastante profundidad las implicaciones sociales de tales medidas, pero a excepción de Browning y Lauria, poco se ha considerado la participación de las municipalidades en el proceso y la forma en que este las afectó. Para finales de la década 1870, la actitud de las municipalidades hacia los ejidos había cambiado considerablemente. Comenzaron a revisar cómo usaban y administraban sus ejidos y a buscar maneras de incorporar más decididamente esas tierras a la agricultura comercial. En cierto modo le siguieron el juego a aquellos que veían a la propiedad corporativa como tradicional y atrasada y aunque nunca se pronunciaron abiertamente por suprimirlos, su anuencia a incentivar los cultivos comerciales en cierto modo minó la legitimidad que hasta entonces los ejidos habían tenido a los ojos de los vecinos. 
Browning destaca que el primer paso en el cambio de funciones de los ejidos lo dio la alcaldía de Mexicanos, que en octubre de 1878 propuso usar fondos municipales para la compra de plantíos de café, cacao, goma y agave, los cuales serían distribuidos gratuitamente entre los ejidatarios que se comprometieran a su cultivo; estableció además conceder la tierra a cualquiera que plantara un cuarto de su parcela con alguna de dichas plantas. Obviamente esa actitud fue muy celebrada por el gobierno central que en marzo de 1879 dio un decreto que ampliaba a escala nacional la resolución de Mexicanos, y cuyo objetivo era "garantizar la propiedad privada y eliminar los obstáculos para su transferencia libre”. Pero además se ordenó a las municipalidades, bajo pena de multa, que plantaran viveros de plantas comerciales y los distribuyeran entre los vecinos..$^{45}$

Durante tres años los pueblos intentaron amoldarse a las nuevas disposiciones e impulsaron la promoción de cultivos comerciales en sus ejidos. Browning considera que hay fuertes indicios de que muchos de ellos "desplegaron un esfuerzo considerable para cumplir la nueva legislación y adaptarse a las nuevas condiciones”. Destaca que entre febrero de 1879 y marzo de 1880, cuarenta y tres municipalidades aprobaron medidas similares a la de Mexicanos. La buena disposición de los pueblos a realizar cambios se refleja en las actas municipales publicadas en el Diario Oficial y en los informes de los gobernadores. Por ejemplo, en septiembre de 1881, el gobernador de Sonsonate destacaba el entusiasmo con que las municipalidades de ese departamento promovían la diversificación de cultivos, especialmente la plantación de viveros de café, cacao, hule, maguey, etc. ${ }^{46}$ Ciertamente que desde unos años antes había habido una presión por parte del gobierno central para que los pueblos reorientaran las tierras ejidales a cultivos comerciales, pero las cantidades de plantíos, especialmente de café, revelan que por lo menos algunas municipalidades estaban muy entusiasmadas y buscaban adecuarse a las nuevas tendencias agrícolas. 


\section{Cuadro 1}

Plantíos de cultivos comerciales de los pueblos de Sonsonate, 1881

\begin{tabular}{|l|r|r|r|r|c|}
\hline \multicolumn{1}{|c|}{ Pueblo } & \multicolumn{1}{c|}{ Café } & \multicolumn{1}{c|}{ Cacao } & \multicolumn{1}{c|}{ Maguey } & \multicolumn{1}{c|}{ Vainilla } & \multicolumn{1}{c|}{ Hule } \\
\hline Sonzacate & & 7,495 & 3,000 & & 7,000 \\
\hline Salcoatitán & 50,000 & & & & \\
\hline El Progreso & 54,000 & & & & \\
\hline Nahuizalco & 23,000 & 1,011 & & & \\
\hline Santo Domingo & & 4,000 & & & \\
\hline Nahulingo & 30,022 & & 3,000 & 800 & 15,000 \\
\hline San Antonio del Monte & & 3,600 & 1,400 & & 10,000 \\
\hline Santa Catarina Masahuat & 44,000 & & & & \\
\hline Acajutla & & & 10,000 & & \\
\hline Izalco & & 4,000 & & & \\
\hline Armenia & 43,000 & & & & \\
\hline Totales & 244,022 & 20,106 & 17,400 & 800 & 32,000 \\
\hline
\end{tabular}

Fuente: Diario Oficial, 25 de septiembre de 1881, págs. 177-180.

El gobernador agregaba que la municipalidad de Sonsonate no había hecho ningún vivero, por lo que podría ser multada con 50 pesos. La de Caluco se había concentrado en la construcción del cabildo, pero tras la visita del funcionario se comprometió a erogar 100 pesos para formar semilleros de cacao, hule y maguey. Por su parte, las de Ishuatán, San Julián, y Cuisnahuat situadas en la costa del bálsamo no habían avanzado en la siembra de café, hule y maguey porque sus terrenos no eran aptos y porque desde tiempo inmemorial se dedicaban a la explotación del bálsamo negro, pero después de la visita que les hizo acordaron iniciar el cultivo de caña de azúcar. $^{47}$

En noviembre del mismo año, la municipalidad de Mexicanos acordó destinar 150 pesos para la compra de semillas de cacao, café y maguey, con el fin de distribuirlas gratis entre los agricultores. También acordó pedir inmediatamente a San Francisco California "mil vástagos de uva para ensayar su cultivo.” Por su parte, Tonacatepeque destinó 200 pesos en el mismo sentido y además comisionó al regidor para ir a Sonsonate a contratar 500 mazorcas de cacao y gestionar la importación de 2,000 vástagos de uva. ${ }^{48}$ Sin embargo, las municipalidades no tuvieron el tiempo suficiente para "probar" la factibilidad de la reconversión productiva. Una encuesta realizada en 1879 sobre la cantidad de tierras parece haber “convencido” al gobierno de la necesidad de suprimir inmediatamente la propiedad colectiva. En la memoria de gobernación 
presentada en marzo de 1880 se decía claramente "Se ha decidido que es imperioso convertir los ejidos en propiedad privada”, lo cual se hizo a partir de marzo de $1882 .{ }^{49}$

Lauria considera que a diferencia de las tierras comunales, la privatización de ejidos fue un proceso relativamente fácil, en parte porque muchas de las tierras ya habían sido privatizadas de hecho y estaban siendo dedicadas a cultivos comerciales, especialmente café, y porque los ejidatarios eran más proclives a la propiedad individual. Sin embargo, esta medida tuvo efectos muy negativos para el poder local. En el plano puramente económico, la ley establecía que los ejidatarios pagarían a las municipalidades "el valor de seis anualidades del canon que tuviesen señalado, pudiendo, si lo solicitaren, disfrutar de un plazo que no excederá de cuatro años, pagando anualmente el interés legal de nueve por ciento"..$^{50}$ Es decir, en un primer momento, la privatización de ejidos dio a las municipalidades ingresos extraordinarios, que seguramente dieron un respiro a sus generalmente deficitarias cuentas. Sin embargo, la falta de previsión, las deudas acumuladas y posiblemente la corrupción en la administración de estos fondos limitaron las posibilidades de inversión y de mejoras en los pueblos. Lo cierto es que cinco años después de decretada la privatización de los ejidos la situación de las rentas municipales había empeorado, pues en muchos pueblos el rubro que daba mayores ingresos era el canon de ejidos y había desaparecido. ${ }^{51}$

La exposición del ministro de gobernación, Santiago Contreras, del año 1887 no deja lugar a dudas sobre las consecuencias de la privatización de ejidos para la rentas municipales: “si bien es verdad que dio notable impulso a la agricultura, privó en cambio a las Municipalidades de las rentas fijas que percibían como canon de los terrenos ejidales; los productos de la venta de dichos terrenos, con el indiferentismo que caracteriza a nuestros Municipios, fueron consumidos improductivamente: a la fecha las Municipalidades carecen en lo general de fondos; y algunas, aún de los necesarios para el pago de sus empleados”. 52

Pero las consecuencias fueron más allá. Los ejidos eran una institución colonial, alrededor de ellos las poblaciones habían desarrollado lazos de convivencia, trabajo y lucha; es decir, su significado sobrepasaba el simple uso de la tierra. Eran un atributo identitario local que fortalecía los lazos solidarios entre los pobladores. La administración y reparto de los ejidos obligaba a una constante y no siempre armoniosa interacción entre ejidatarios y munícipes que repercutía en las disputas de poder local. El reparto y administración de los ejidos fue un punto clave en la agenda de los grupos que se disputaban el poder municipal. ${ }^{53}$ Como muy bien lo señala 
Antonio Annino, "para los pueblos, fueran o no indígenas, la tierra nunca fue solo un recurso económico, sino en primer lugar una fuente de derechos políticos, y por ende de libertades colectivas frente al Estado.”54 Es decir, que al mantener el control sobre la tierra aseguraban también su protagonismo político y su cohesión interna, pero estos atributos se perdieron cuando los ejidos fueron privatizados.

La privatización de los ejidos quitó a las municipalidades una importante fuente de ingresos, pero no las libró de otras responsabilidades ligadas a la promoción y protección de la agricultura. El Código de Agricultura de 1893 mandaba a las comunas la formación anual de almácigos de plantas comerciales para ser distribuidas entre los agricultores; el cuido y conservación de los ríos; la destrucción de ranchos y viviendas en despoblados que fueren sospechosas de albergar ilícitos, y auxiliar a los propietarios cuyas tierras hubieran sido invadidas por extraños. También se les encargaba llevar un registro de jornaleros y capturar a los "quebradores de trabajo" al primer requerimiento del interesado e intervenir a favor de los trabajadores cuando no se les pagare su salario. ${ }^{55}$ En realidad, el Código era simplemente una ampliación y actualización de lo establecido en las leyes recopiladas por Isidro Menéndez en 1854 y la "Ley sobre jornaleros y creación de Jueces de Agricultura” dada bajo el gobierno de Francisco Menéndez en 1881. ${ }^{56}$ En todo caso, las obligaciones de las municipalidades con respecto a la agricultura no desaparecieron, pero se reorientaron a la protección de agricultores y propietarios y al control y disciplina de la mano de obra.

\section{Las luchas municipales por la autonomía a finales del XIX}

Las municipalidades no se quedaron de brazos cruzados ante la creciente pérdida de autonomía y la reducción de sus recursos. Para finales de la década de 1880, hicieron una fuerte y constante demanda para que se les aumentaran las rentas, a la vez que pugnaban por una efectiva autonomía municipal. En marzo de 1889 la municipalidad capitalina decía que ante la desaparición de los ejidos, que eran el rubro de propios que más ingresos les daba, era preciso aumentar los arbitrios. "Se necesita, pues, una tarifa municipal decretada concienzuda y sabiamente por el poder legislativo... procurando el progreso de los fondos de dichas corporaciones en armonía con las necesidades del pueblo." 57

Unos meses antes, algunos diputados mocionaron para que se diera a las municipalidades la renta de aguardientes y se crearan policías departamentales bajo jurisdicción municipal. Tal 
iniciativa creó grandes expectativas. A finales de abril del mismo año, el corresponsal de "El Municipio Salvadoreño" en Cuscatlán, decía que se esperaba con ansiedad la publicación en el Diario Oficial del decreto. Agregaba que algunos municipios ya habían planeado en qué invertirían las rentas: puentes, calzadas, casas de escuela, etc. Muy previsores también pensaban en una policía rural para combatir el contrabando de licores y de ese modo aumentar sus ingresos. Pero una aclaratoria del editor señalaba: "Nuestro estimable corresponsal no recuerda o no ha leído que el proyecto a que se refiere no tuvo vida legal, por circunstancias que son del dominio público." ${ }^{58}$

La no aprobación del decreto generó mucho descontento en las municipalidades. La de San Salvador lamentó que tales proyectos "fueron por desgracia nuestra, nada más que una esperanza fugaz, un aborto del patriotismo, murieron antes de nacer”. Ese comentario fue un buen pretexto para extenderse sobre el tema de la autonomía municipal. Decía que el poder municipal "y la libertad de que necesariamente debe estar dotado, será ilusorio, mientras no se le asignen los medios necesarios de existencia, ni puede ser benéfico sin los elementos precisos para llenar los fines que le son confiados... la independencia no se aclimata a ningún ser que carece de vida propia". Agregaba que la ley establecía claramente que las municipalidades "no dependen de Poder ninguno ni tienen que esperar iniciativa de ninguna especie para llenar sus atribuciones, sin que pueda declinárseles por funcionario alguno ninguna especie de responsabilidad, sino solamente en el caso de infracción de la ley, ya por traspasarla, ya por no cumplirla”; pero sostenía que esa independencia legal sería letra muerta, "mientras las municipalidades no tengan rentas propias y vivan como pordioseros, pidiendo ya al Congreso, ya al Gobierno, una miga para satisfacer su mayor necesidad." 59

El decidido tono de la nota adquiere mayor significado al ser suscrito por la más importante municipalidad del país, que había encargado a su secretario la dirección del semanario. El 4 de julio publicó un artículo en que planteaba las dos posiciones en boga frente a la cuestión municipal. Unos sostenían que la municipalidad "no es otra cosa que una rueda de la máquina administrativa, y de consiguiente su impulso no lo recibe de sus administrados sino del Poder Ejecutivo, que es el eje de la gran máquina que gira dentro de la gran órbita constitucional”. Por el contrario, otros argumentaban que es una instancia con vida propia "que necesita independencia y autonomía para llenar los fines de su institución.” La alcaldía de San Salvador optaba claramente por la última posición, “y no creemos que esa autonomía sea nociva a los intereses generales de 
la nación... Lo que se necesita es aclarar los límites de esa independencia”, los cuales serían los intereses locales y territoriales. ${ }^{60}$

Las preocupaciones de la municipalidad capitalina tenían sobrada justificación. En febrero de 1890 elaboró una propuesta de tarifa municipal, aduciendo que "en el estado actual de penuria en que el Ayuntamiento de la capital de la república se encuentra; cargado como está de una deuda considerable y sin elementos para satisfacer sus múltiples necesidades, se hace urgente la reforma de la tarifa para crear una renta equivalente a los gastos”. ${ }^{61}$ Un mes después, J. M. Paredes, alcalde de San Salvador, presentó el proyecto a la Asamblea. La nueva tarifa establecía que las “cajas de música ambulantes” pagarían 25 pesos al mes, considerando las buenas ganancias de sus dueños, las molestias que causaban a algunos vecinos y la competencia desigual que hacían a la "música nacional”. Así mismo se aumentaba a 200 pesos mensuales la carga tributaria de los montepíos, "que trafican con la pobreza". También pedían el producto de la alcabala. ${ }^{62}$ Cuando el proyecto pasó a la Asamblea, esta dijo que apoyaba la medida, pero consideraba indispensable tener la opinión del Ejecutivo sobre algunos puntos. ${ }^{63}$ No se encontró una resolución definitiva.

Los esfuerzos de las municipalidades por preservar su autonomía y aumentar sus rentas no prosperaron. El ejecutivo se negó sistemáticamente a cederles rentas más productivas, como las de aguardiente, dejándoles los arbitrios que no reportaban ingresos significativos.

En 1894 Lisandro Blandón presentó una tesis de grado sobre el problema municipal, la cual da un claro panorama de lo que habían sido las relaciones entre el gobierno central y las municipalidades a lo largo del siglo.

"Cuando los Congresos han puesto manos en la institución municipal, ha sido para causarle daños sin proporcionarle remedio alguno. Se le han limitado sus funciones para aumentar las del Poder General, se les han cercenado sus rentas para llevarlas á las arcas nacionales y de esta manera viene de día en día sufriendo invasiones que de no ponerles término llegarán á nulificar completamente su acción. (...)

Últimamente se quitó a los municipios el producto de alcabala interior, el fondo de caminos, el producto del destace de ganado y el de otros ramos que contribuían á darle vida propia. (...)

Estos actos demuestran de una manera evidente, que el Gobierno procura siempre ensanchar su esfera de acción, aún invadiendo las peculiares de las demás instituciones 
y pone de manifiesto la tendencia del Poder Ejecutivo á centralizar todos los ramos de la administración, aún en sus detalles más insignificantes." ${ }^{64}$

Una de las cuestiones que más resentía Blandón era, que a pesar de que las constituciones siempre sostuvieron la independencia municipal, nunca se legisló claramente sobre sus atribuciones y los límites de su autonomía, dejando amplio margen para la injerencia del Ejecutivo, especialmente a través de los gobernadores departamentales. Señalaba que las leyes abundaban en obligaciones para la municipalidad, y preguntaba:

“¿Pero cómo queréis que cumpla debidamente con semejantes deberes si por una parte le arrebatáis de sus manos las contribuciones especiales de sus vecinos para llevarlas á las Arcas del Estado, y por otra, el Gobierno en uso de sus facultades le reconoce arbitrios tan exiguos que apenas bastan para pagar sus sueldos á los empleados?... Como los arbitrios constituyen en la actualidad todo el fondo municipal, y aquellos dependen de la voluntad del Ejecutivo, cuya sanción es inevitable por la ley vigente para que sean pagados por la comunidad, las rentas municipales, o sea el elemento vital, tienen existencia precaria.”65

Quizá Blandón exageraba un poco. El problema central no era la aprobación de los arbitrios; ciertamente era difícil, pero se lograba. La dificultad mayor era que pocos municipios tenían recursos económicos suficientes para producir ingresos suficientes a las municipalidades por la vía de los arbitrios.

Como se dijo antes, en las zonas productoras de café fue posible gravar ese producto, pero en otras partes en que la economía era menos dinámica esa opción rentística no era posible. La caficultura demandaba obras y servicios; ante la falta de recursos municipales y la renuencia o incapacidad del gobierno central para realizar las obras requeridas se recurrió a una nueva modalidad de gestión: las "Juntas de Fomento". Estas eran conformadas por "personas distinguidas” de la localidad y por munícipes; generalmente se dedicaron a obras puntuales: carreteras, construcción de escuelas y cabildos, introducción de agua, etc. Como se organizaban con fines muy específicos, generalmente lograban su cometido. Este tipo de Juntas, resultan un espacio social muy interesante. En ellas concurrían el poder político, los intereses económicos y el prestigio social. Las gestiones que debían realizar a nivel regional e incluso nacional permitían 
que sus miembros se integraran a redes de poder más amplias. Para 1908 había Juntas en todas las cabeceras departamentales y en varias ciudades y pueblos cafetaleros.

Un ejemplo interesante es el de Santiago de María. Desde su creación esta población resentía la falta de agua, un problema que ninguna municipalidad había podido resolver. En 1892 se organizó una “Junta de agua”, conformada por Pedro Poch, Casimiro Donnadieu, Juan Shonemberg y Alberto Avila, todos importantes cafetaleros. En un año construyeron una cañería de 15 kilómetros que llevó el agua al pueblo y sus alrededores. Tanto significó este logro que por varios años se celebró el aniversario de la inauguración. Sin embargo, pronto surgieron conflictos entre los medianos y grandes cafetaleros por la asignación de las pajas y los cobros, al grado que en 1898 el servicio pasó a manos de la municipalidad. ${ }^{66}$ En todo caso, la Junta logró su cometido y de algún modo puso en cuestión la capacidad del gobierno local, que nunca pudo introducir el agua al pueblo.

Para mediados de la década de 1890 la siempre presente precariedad rentística de la mayoría de las municipalidades había llegado a ser alarmante. Cualquier arbitrio debía ser aprobado por el Ejecutivo, y aunque fuesen aprobados, los ingresos eran exiguos. Como ya se dijo antes, solo el canon de ejidos representó un ingreso significativo y relativamente constante. No es de extrañar entonces que el citado Blandón propusiera una reforma constitucional, cuyos principales puntos eran:

1. Organización general de la policía bajo la autoridad municipal.

2. Restituir a las municipalidades la enseñanza y la recaudación y administración de los fondos dedicados a su sostenimiento.

3. Dejar a las municipalidades la conservación y reparación de caminos, y la recaudación y administración de contribuciones especiales.

4. Dar a la municipalidad la formación de la estadística local, el fomento de la industria y la agricultura, el ornato, salubridad y beneficencia pública, dotándolas de rentas especiales.

5. Que la recluta para el ejército se haga bajo la dirección municipal, y que las milicias queden bajo el mando del alcalde, pero con la supervisión de los Comandantes departamentales.

6. Que el establecimiento de arbitrios se haga por la Asamblea, sin intervención del Ejecutivo. 
Obviamente la iniciativa de Blandón no prosperó, pero sí tuvo buena acogida entre las municipalices, al grado que la de Nueva San Salvador, publicó la tesis de Blandón e hizo comentarios muy positivos sobre ella.

La prueba de que no hubo mayores cambios en el manejo de la cuestión municipal por parte del ejecutivo, desde finales del XIX hasta la primera mitad del siglo XX, se encuentra en los trabajos Everett Alan Wilson y Patricia Parkmam. Wilson destaca que en la década de 1939 el régimen de Hernández Martínez cerró los espacios políticos locales y quitó a las municipalidades sus fondos propios. Parkmam señala que Martínez fortaleció sobremanera el poder presidencial, suprimiendo la autonomía formal de los gobiernos municipales. Resulta muy significativo que Martínez impusiera el nombramiento de los alcaldes municipales y quitara a las municipalidades todos sus ingresos propios. Cualquier acto del poder local debía contar con la aprobación de Martínez o uno de sus funcionarios cercanos. ${ }^{67}$

Esas afirmaciones son corroboradas por otras fuentes. El Plan de gobierno del Partido Revolucionario de Unificación Democrática(PRUD) de 1950 decía: "El municipio es la institución primaria en un sistema democrático de organización política. Con un descuido que viene de siglos, el municipio salvadoreño se encuentra atrasadísimo, tanto en su aspecto político como en el administrativo... el municipio debe gobernarse en forma autónoma, con las únicas limitaciones que exigen la interdependencia gubernamental en general, y aquella que provienen de las leyes que garantizan los intereses generales del país.”68 Más adelante decía que "Las municipalidades deben integrarse por elementos electos directamente por los ciudadanos del municipio, por voto universal y libre, y que funcionarán sin otra intervención del Gobierno Central que aquella que la ley prevé para garantía del orden... la autonomía municipal no debe limitarse al asunto político, sino extenderse paulatinamente al orden económico y al administrativo, hasta que puede gozar de la mayor independencia, sin peligro de que los recursos comunales sean mal invertidos.”69

Consideraciones de ese tipo abundan en las fuentes oficiales del XIX y XX, pero nunca hubo la voluntad política de reorientar el rumbo de la administración municipal. Los únicos cambios significativos se dieron después de los Acuerdos de Paz de 1991, pero los avances han sido muy problemáticos y contradictorios. Pareciera que para el ejecutivo, la descentralización conlleva reasignación de responsabilidades a las municipalidades, pero sin la contraparte esencial que es la reasignación de recursos. Esa posición hace que incluso una destacada alcaldesa, militante del 
partido en el poder reaccione de este modo a las iniciativas del Ejecutivo: "Las municipalidades estamos abiertas a la descentralización, pero con los respectivos ingresos. No es que estemos pidiendo más dinero, pero una descentralización tiene que ir acompañada del financiamiento." 70

\section{Conclusiones}

Las reformas liberales fueron la culminación de un largo proceso de afianzamiento del poder central y construcción del Estado en El Salvador. Aunque la historiografía salvadoreña en general ha tendido a verlas como una ruptura, es importante destacar que estas solo pueden ser adecuadamente entendidas teniendo en cuenta los cambios realizados en la década de 1860, especialmente en lo que se refiere a economía y al trabajo de fortalecimiento del poder central y sometimiento del poder local. En este punto en particular, las reformas liberales no representan un punto de inflexión determinante; más bien son la culminación de un proceso iniciado lustros atrás.

Puede afirmarse que los gobernantes del último tercio del XIX usufructuaron de los esfuerzos de Gerardo Barrios y especialmente de Francisco Dueñas para someter al poder local al dominio del Ejecutivo. En las décadas de 1870 y 1880, simplemente se afinaron los mecanismos de control sobre las municipalidades, al tiempo que se reducían considerablemente sus esferas de acción y sus rentas, lo cual fue posible porque el gobierno central ya podía asumir directamente tareas como educación, organización de milicias y de registros estadísticos. El aumento de las capacidades de acción y supervisión de los funcionarios, junto con las facilidades brindadas por la infraestructura - carreteras, telecomunicaciones - y el fortalecimiento del ejército permitió al Ejecutivo supervisar y dominar el accionar municipal, al punto de generar reacciones.

Efectivamente, a finales de la década de 1880, las municipalidades intentaron revertir el proceso. Pero al igual que aconteció en décadas anteriores la lucha se dio de manera aislada, aunque vale destacar que el mayor protagonismo lo tuvieron las municipalidades de las ciudades más importantes. Aún así, los resultados fueron nulos. A los ojos del Ejecutivo, el sometimiento del poder local era un ejemplo más de éxito y se mostraba tan efectivo que la tendencia se mantuvo a lo largo del siglo XX. Tan solo comenzó a cuestionarse en la década de 1980, y a discutirse después de los Acuerdos de Paz, cuando el debate sobre la descentralización cobró fuerza, pero sin que hasta la fecha haya producido resultados efectivos y satisfactorios. 


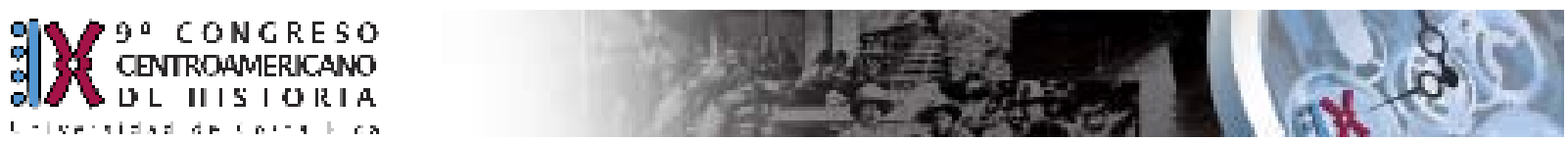

Indexaciones: Repositorio de Revistas UCR, DIALNET, Latindex, REDALYC Directorio y recolector de recursos digitales del Ministerio de Cultura de España, Directory of Open Access Journals. Diálogos Revista Electrónica de Historia ISSN 1409-469X. Número especial 2008. Dirección web: http://historia.fcs.ucr.ac.cr/dialogos.htm

$1 \quad$ Una notable, pero insuficiente excepción son los trabajos de Rodolfo Cardenal, El poder eclesiástico en El Salvador. San Salvador, Dirección de Publicaciones e Impresos, 2001, caps. 5 y 7; y Santiago Montes, Etnohistoria de El Salvador. 2 Tomos, San Salvador, Dirección de Publicaciones e Impresos, 1977.

2 Véase, Héctor Lindo. La economía de El Salvador en el siglo XIX. San Salvador, Dirección de Publicaciones e Impresos, 2002, y Aldo Lauria-Santiago. Una república agraria. Los campesinos en la economía y la política de El Salvador en el siglo XIX. San Salvador, Dirección de Publicaciones e Impresos, 2002.

$3 \quad$ Ejemplo de ello son los trabajos de David Joaquín Guzmán, Teodoro Moreno, José Antonio Cevallos, Esteban Castro y otros. Todos ellos pugnaron por "civilizar” y ladinizar al indio, como única vía para sacarlo de la "postración” en que según ellos vivía. Nadie lo tuvo más claro que Guzmán, para quien el indio era "un ser pasivo en el estado civil y social de nuestra sociedad á pesar de estar plenamente rehabilitado por las leyes de la República. Es necesario que el espíritu realmente liberal y humanitario de nuestras instituciones penetre por todos lados en el hogar del indígena, instruyéndole, sacándole de la apatía, y si es posible haciéndole desaparecer gradualmente en la masa de la civilización actual que es por una parte la suerte reservada á los vestigios espirantes de otras civilizaciones ya muertas y por otra la gloriosa misión encomendada al apoyo paternal de los gobiernos liberales e ilustrados.” David J. Guzmán, Apuntamientos sobre la topografía física de la República de El Salvador. San Salvador, Tipografía El Cometa, 1883, pág. 507. El énfasis es mío.

$4 \quad$ Una interpretación interesante y sugerente sobre esta faceta de la vida política decimonónica aparece en los trabajos de Sonia Aldas Mejía, "Las revoluciones y el "sagrado derecho de insurrección de los pueblos" en Centroamérica, 1838-1871; Pactismo y soberanía popular”. En Actas del III Congreso de historiadores latinoamericanistas (ADHILAC), Pontevedra, octubre de 2001. Una buena síntesis de la evolución de los estudios sobre historia política hispanoamericana en las últimas décadas se encuentra en Federica Morelli. "Entre el Antiguo y el Nuevo Régimen. La historia política hispanoamericana del siglo XIX.” En Historia Crítica, \# 33, enero-junio 2007, pp.122-155.

$5 \quad$ La Constitución de 1871 decía: “En presencia de Dios, Supremo legislador del Universo, y en nombre del pueblo salvadoreño, el Congreso Nacional Constituyente decreta, sanciona y promulga la siguiente Constitución". La de 1883 fue mucho más lejos; simplemente afirmaba: "En nombre del pueblo salvadoreño, el Congreso Nacional Constituyente, decreta, sanciona y proclama la siguiente Constitución.” Ricardo Gallardo. Constituciones de El Salvador, Tomo I, Madrid, Ediciones Cultura Hispánica, 1961, págs. 387 y 485.

6 Para mayores detalles sobre el conflicto entre liberales y clero en la década de 1870, véase: Rodolfo Cardenal, El poder eclesiástico, capítulo 2.

$7 \quad$ Héctor Lindo, La economía de El Salvador, págs. 192-193. En la memoria de hacienda de 1874 se puede apreciar la lectura que entonces se hacía sobre los productos de exportación, al decir: "El consumo del Añil puede disminuirse por el descubrimiento de tintes que lo vayan reemplazando y tal vez llegue su precio a ser tan poco remunerativo como el de la cochinilla y a desaparecer las rentas que de él proceden; pero en cambio tenemos por delante el halagüeño porvenir del café cuyo cultivo se aumenta notablemente en la República, prometiendo por su buena calidad y la abundancia con que se produce llegar a ser un ramo pingüe de nuestra riqueza agrícola”. José Larreynaga, Memoria de Hacienda y Guerra, 1874. San Salvador, Imprenta Nacional, 1875, pág. 6.

8 Héctor Lindo, La economía de El Salvador, págs. 223 y 229. Similares consideraciones hace Robert G. Williams. States and Social Evolution. Coffee and Rise of National Governments in Central America. The University of North Carolina Press, 1994, págs. 205-239.

$9 \quad$ Aldo Lauria-Santiago, Una república agraria, pág. 342.

10 Aldo Lauria-Santiago, "Land, Community, and Revolt in Late-Nineteenth-Century Indian Izalco, El Salvador”. Hispanic American Historical Review, 79:3, 1999, pág. 505.

11 Véase, Héctor Lindo, La economía de El Salvador, págs. 260-264; Carlos Gregorio López Bernal, 
Tiempo de liberales y reformas. En El Salvador; la república. San Salvador, Fomento Cultural Banco Agrícola, tomo I, 2000, págs, 256-257; y Patricia Alvarenga, Cultura y ética de la violencia. El Salvador 1880-1932. San José, EDUCA, 1996, págs. 173-190.

12 Citado por Francisco de Paula Suárez, Noticias generales de la República de El Salvador. Lima, Tipografía La Patria, 1874, pág. 25.

13 Maurice de Perigny. En Silvia Dutrénit, El Salvador. México, Editorial Patria, 1989, pág. 61.

14 Mariano Fernández, gobernador de Sonsonate, al Ministro de lo interior, 4 de febrero de 1871. Archivo

General de la Nación, Fondo Quemados, Gobierno político departamental de Sonsonate, caja 3, 1867-1886. En adelante se citará AGN.

15 AGN, Fondo Quemados. Gobierno Político Departamental de San Vicente, caja 2, año 1872.

16 Antonio Grimaldi, ministro de lo interior, al gobernador de San Vicente, 10 de mayo de 1872. Idem.

En febrero 1879 se pedía al gobernador de San Vicente investigar quiénes eran los responsables de suspender las

líneas del telégrafo e imponerles una multa. AGN, Fondo Quemados. Gobernación Departamental de San Vicente, caja 1, año 1879.

17 Informe de la Gobernación del Departamento de Cabañas, Diario Oficial, 4 de octubre de 1881, pág.

316.

18 Carlos Gregorio López Bernal, Tradiciones inventadas y discursos nacionalistas: El imaginario nacional de la época liberal en El Salvador, 1876-1932. San Salvador, Editorial Universitaria, 2007, pág. 59.

19 El gobernador de San Salvador, a la presidencia. San Salvador, diciembre de 1897. AGN, Ministerio de Gobernación, siglo XIX, varios, caja 1.

20 Para mayores detalles sobre este sistema, véase: Aldo Lauria-Santiago, Los indígenas de Cojutepeque, la política faccional y el Estado en El Salvador, 1830-1890. En Jean Piel y Arturo Taracena (editores) Identidades nacionales y Estado moderno en Centroamérica, San José, Editorial de la Universidad de Costa Rica-FLACSO, 1995; Patricia Alvarenga, Cultura y ética; y Carlos Gregorio López Bernal, Tiempo de liberales y reformas.

21 Patricia Alvarenga, Cultura y ética, págs. 33-39.

22 Diario Oficial, 12 de marzo de 1881, págs. 253 y 256.

23 Santiago I. Barberena, Descripción geográfica y estadística de la República de El Salvador. San Salvador, Imprenta Nacional, 1892, pág. 67; y Patricia Alvarenga, Cultura y ética, págs. 145-146.

24 Memoria presentada a la Asamblea Nacional por el Ministro de Gobernación, Marina y Guerra, don Domingo Jiménez. Diario Oficial, 15 de marzo de 1894, pág. 327.

25 Documentos varios. Informe del Ministro de Gobernación. Diario Oficial, 2 de agosto de 1888, pág. 978. 26 El alcalde de Comasagua al gobernador de La Libertad, 16 de febrero de 1887. AGN, Gobernación de La Libertad, caja 79, Libro de correspondencia de la alcaldía de Comasagua.

27 Informe de la municipalidad de San Esteban, 2 de diciembre de 1872. AGN, Gobernación de San Vicente, caja 1, 1872.

28 Informe del Gobernador del departamento de Cuscatlán, Diario Oficial, 31 de agosto de 1881, págs. 197198.

29 Informe semestral del gobernador del departamento de San Vicente, Diario Oficial, 23 de julio de 1881, págs. 81- 82. Véase además: Informe de la Gobernación departamental de san salvador, Diario Oficial, 2 de septiembre de 1881; Informe de la Gobernación del Departamento de Cabañas sobre la agricultura, Diario Oficial, 4 de octubre de 1881; Informe del gobernador del departamento de Sonsonate, Diario Oficial, 25 de agosto de 1881; Informe de Gobernador de Ahuachapán al Director General de Instrucción Pública, Diario Oficial, 22 de julio de 1881.

30 Con estas boletas se llevaba el control de importante impuesto de beneficencia o caminos; una contribución que debía pagar todo varón entre 16 y 60 años, equivalente a 4 reales o dos días de trabajo en obras públicas. El dinero era recolectado por los alcaldes que debían dar cuenta de él a las autoridades superiores. 


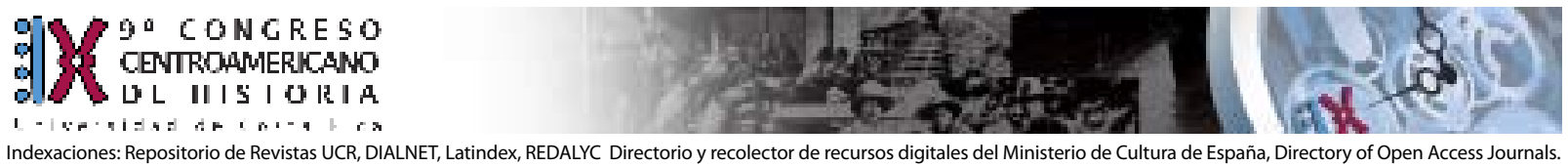

Indexaciones: Repositorio de Revistas UCR, DIALNET, Latindex, REDALYC Directorio y recolector de recursos digitales del Ministerio de Cultura de España, Directory of Open Access Journals. Diálogos Revista Electrónica de Historia ISSN 1409-469X. Número especial 2008. Dirección web: http://historia.fcs.ucr.ac.cr/dialogos.htm

31 Informe del gobernador político del departamento de San Miguel, al señor ministro de fomento. En Memoria general de El Salvador, 1888, págs. 472-478.

32 Memoria de gobernación, marina y guerra, presentada por Domingo Jiménez, 1892. San Salvador, Tipografía La Luz, págs. 339-345. Una visión muy actualizada y sugerente de la cuestión fiscal municipal y las correlaciones de poder a finales del XIX en El Salvador aparece en Antonio Acosta, "Municipio, Estado y crisis económica. El Salvador, 1870-1880. Una contribución al análisis desde las haciendas municipales.” Revista de Indias, \# 240, 2007, pp. 367-402.

33 Toda esta información está en AGN, Fondo varios, Colección de notas de la Gobernación, Gobierno político departamental de San Miguel, caja 1, año 1900.

34 Reglamento para la administración del ramo de aguardientes por cuenta del Estado, 1873. AGN, Impresos, Tomo XX, libro 1, págs. 2-23

35 Memoria de la Secretaría de Estado en los Ramos de Hacienda y Guerra, para el año 1874, presentada por el Secretario de Estado en los Departamentos de Hacienda y Guerra don José Larreynaga. San Salvador, Tipografía Nacional, 1875, pág. 5.

36 La ambigüedad de la definición dio lugar a conflictos entre vecinos y autoridades; cada uno tomaba de la ley la acepción que más le favorecía. Pero en general es claro que las autoridades usaban criterios muy laxos para la elaboración de los padrones. Véase, Antonio Acosta. Municipio, Estado y crisis económica.

37 AGN, Fondo Leyes y códigos, caja 5. Reformas a los códigos, Ramo de gobernación. San Salvador, Imprenta El Cometa, 1889, págs. 57-58.

38 Idem., págs. 147-148.

39 AGN, Fondo Leyes y códigos, caja 13. Hilario Alvarado, Instrucción práctica sobre el modo de llevar las cuentas municipales de la República del Salvador. San Salvador, Imprenta Nacional, 1888.

40 Informe del señor Contador de Propios y Arbitrios, don Hilario Alvarado. Diario Oficial, 26 de julio de 1889, pág. 901.

$41 \quad$ Memoria de gobernación y fomento del año 1882, presentada por Adán Mora, pág. 155.

42 AGN, Fondo Leyes y códigos, caja 9. Anuario de legislación de la República de El Salvador, 1894. San

Salvador, Imprenta 7 de junio, 1894. Nombramiento de secretarios municipales, págs. 54-55.

43 Diario Oficial, 6 de noviembre de 1881, pág. 437.

44 Para mediados de 1887 el Diario Oficial, incluía variados cuadros anexos de la Oficina de Estadística, por ejemplo: Cuadro de los académicos de la república, 1886; Cuadro matrimonios celebrados, 1884; Cuadro de importaciones, 1886; Cuadro de enfermedades asistidas en el Hospital de San Salvador, 1886; Cuadro de nacimientos 1884, 1885 (con registro de indígenas y blancos); Cuadro de exportaciones, 1886 y Cuadro de defunciones, 1884. Para entonces la Oficina de Estadística estaba a cargo de Rafael Reyes.

45 David Browning, El Salvador, la tierra y el hombre. San Salvador, Dirección de Publicaciones e Impresos, 2000, págs. 302-306.

46 Informe del gobernador de Sonsonate. Diario Oficial, 25 de septiembre de 1881, págs. 177-180.

47 Idem.

48 Actas Municipales de Mejicanos y Tonacatepeque. Diario Oficial, 16 de noviembre de 1881, pp. 470-

471. Un detalle de los trabajos de las municipalidades por incentivar los cultivos comerciales se encuentra en Browning, El Salvador, la tierra y el hombre, págs. 310-313.

49 Idem., págs. 335 y 341-342.

50 Disposiciones relativas a la extinción de ejidos. En Boletín de Agricultura, Tomo 9, 3a época, № 11 , 1909, pág. 522.

$51 \quad$ Sobre la importancia del canon de ejidos para las rentas municipales, véase Carlos Gregorio López Bernal, Poder central y poder local en la construcción del Estado en El Salvador, 1840-1890. Tesis de doctorado en Historia, Universidad de Costa Rica, mayo de 2007, cap. 2. 


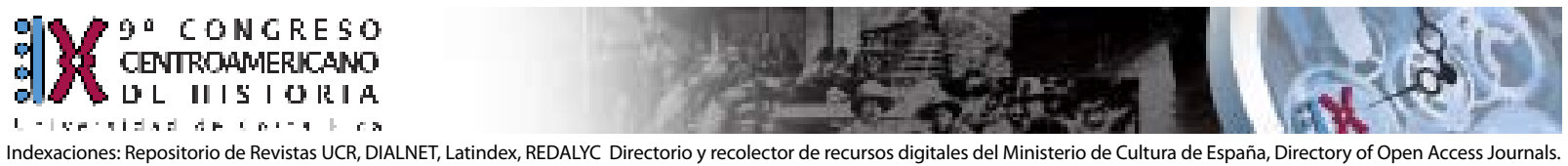

Indexaciones: Repositorio de Revistas UCR, DIALNET, Latindex, REDALYC Directorio y recolector de recursos digitales del Ministerio de Cultura de España, Directory of Open Access Journals. Diálogos Revista Electrónica de Historia ISSN 1409-469X. Número especial 2008. Dirección web: http://historia.fcs.ucr.ac.cr/dialogos.htm

52 Memoria de Gobernación para el año 1887, presentada por el Dr. Santiago Contreras, pág. 8. Es preciso acotar que algunos municipios de las zonas cafetaleras lograron gravar el grano, con lo cual suplieron - al menos en parte - el canon ejidal. Por ejemplo, desde 1886 Santiago de María cobró 25 centavos por cada carreta cargada de café (en uva, cereza y oro) que saliera del pueblo. En 1896, cobraba además 6 centavos por cada quintal de café producido en su jurisdicción. Oscar Antonio Campos, Cafetaleros de Santiago de María: La formación de un poder micro-regional en la sierra de Tecapa de Usulután, 1874-1917. Tesis de licenciatura en Historia, Universidad Tecnológica de El Salvador, 2006, pág. 76.

53 Buen ejemplo de ello son los conflictos entre indios y ladinos por el control del poder municipal en Apastepeque; véase Carlos Gregorio López Bernal. Poder central y poder local, cap. 2. Lauria hizo un estudio muy revelador sobre los conflictos en torno a la privatización de tierras comunales en Izalco y sus implicaciones para el poder municipal. Véase, Aldo Lauria, Land, Community, and Revolt.

$54 \quad$ Antonio Annino, Cádiz y la revolución territorial de los pueblos mexicanos 1812-1821. En Antonio Annino, (Coordinador) Historia de las elecciones en Iberoamérica, siglo XIX. México, Fondo de Cultura Económica, 1995, pág. 178.

55 Código de agricultura, 1893. San Salvador, Tipografía La Luz, 1893, págs. 206-233. El Código comprendía además una Ley de policía agrícola que regulaba las acciones de los inspectores de policía y los alcaldes auxiliares en todo lo concerniente a la protección de la riqueza agrícola y el control de la mano de obra. $56 \quad$ Ley sobre jornaleros y creación de Jueces de Agricultura. Diario Oficial, 17 de marzo de 1881.

$57 \quad$ Propios y arbitrios. En El Municipio Salvadoreño. Órgano de los intereses municipales del departamento de San Salvador, 21 de marzo de 1889, pág. 2. En Colecciones Especiales. Biblioteca P. Florentino Idoate, S.J. de la Universidad Centroamericana José Simeón Cañas. U.C.A.

$58 \quad$ El Municipio Salvadoreño, 30 de mayo de 1889, pág. 2.

$59 \quad$ El poder municipal, en El Municipio Salvadoreño, 17 de abril de 1889, pág. 1.

60 El Municipio Salvadoreño, 4 de julio de 1889, pág. 1.

61 El Municipio Salvadoreño, 13 de febrero de 1890, pág. 1.

62 El Municipio Salvadoreño, 13 de marzo de 1890, pág. 1.

63 Sesiones de la Asamblea. Diario Oficial, 25 de marzo de 1890, pág. 353.

64 Lisandro Blandón. "El Municipio en un país republicano debe organizarse de tal manera que la autonomía que por naturaleza le corresponde quede garantizada contra la acción política del ejecutivo”.

(23/11/1894). En Revista Municipal. Órgano de la municipalidad de Nueva San Salvador, Tomo I, No 8, agosto de 1896, pág. 9. El énfasis es mío.

65 Idem., pág. 10.

66 Oscar Antonio Campos, Cafetaleros de Santiago de María, pág. 145. Cuando en 1916, Santiago de María inauguró su cabildo e inició la construcción de la cárcel, la municipalidad agradeció especialmente a Carlos Amory (que fue alcalde por tres años y diputado en 1912, 1915, 1916, y 1917), y a la Junta de Fomento. Dejaban bien claro que no habían contado con ayuda del Gobierno. Idem., pág. 157.

67 Everett Alan Wilson, La crisis de la integración nacional en El Salvador, 1919-1935. San Salvador, Dirección de Publicaciones e Impresos, 2004, págs. 219-20; y Patricia Parkmam, Insurrección no violenta en El Salvador. San Salvador, Dirección de Publicaciones e Impresos, 2003, pág. 60. En cierto modo, Martínez realizó los proyectos centralizantes que Gerardo Barrios no pudo ejecutar en la década de 1860.

68 Plan de gobierno del Partido Revolucionario de Unificación Democrática. En Revista Informaciones de El Salvador, Secretaría de Información de la Presidencia de la República, № 3, octubre de 1950, pág. 13. El énfasis es mío.

69 Idem. El énfasis es mío. Similares consideraciones hacía en la década de 1980, Antonio Morales Erlich. El municipio en el proceso de desarrollo. San José, Instituto de Estudios Políticos, 1979.

70 Milagro de Navas, alcaldesa de Antiguo Cuscatlán. El Diario de Hoy, 27 de diciembre de 2006, pág. 16. 